\title{
Evaluation of ECG Recording Applications of Non-Physician Healthcare Workers Working in Emergency Departments
}

\section{Acil Servislerde Çalışan Hekim Dışı Sağlık Personellerinin EKG Çekim Uygulamalarının Değerlendirilmesi}

Azize Aydemir ${ }^{1} \odot$

\section{ABSTRACT}

Aim: The aim of the study was to identify the right and wrong applications of non-physician healthcare workers working in the emergency department (ED) on the standard ECG method.

Material and Methods: The study was conducted in the ED of two hospitals in Yozgat province. The data were collected in three stages, in which healthcare workers recording ECGs were observed, emergency medicine specialists evaluated each ECG recording, and the questionnaire on the ECG shooting method was applied. Frequency and percentage values in the descriptive statistics of the study and Pearson Correlation analysis were used to determine the relationship between variables.

Results: There was no statistically significant relationship between healthcare workers' level of knowledge about recording ECG and the correct execution of the procedure $(p>0.05)$. Emergency medicine specialists who interpreted the ECG reported that there was a situation that limited interpretation in nearly half of the ECG reports, which was due to the shooting error in $46 \%$ of them, and $22 \%$ of the ECG shootings were repeated. Chest electrodes were highly positioned incorrectly $(100 \%-80 \%)$ in both theory and in practice.

Conclusion: It was observed that there was no relationship between the knowledge of the healthcare professionals who recorded the ECG about the procedure and their behavior during the procedure, and there was at least one shooting error in almost half of the ECGs taken in the ED.

Keywords: Electrocardiography, healthcare worker, emergency department, diagnosis

\section{Öz}

Amaç: Araştırmanın amacı acil serviste (AS) çalışan hekim dışı sağlık personelinin standart EKG çekme yöntemine ilişkin doğru ve yanlış yaptıkları uygulamaların tanımlanmasıdır.

Gereç ve Yöntemler: Araştırma Yozgat ilinde bulunan iki hastanenin AS'de yapılmıştır. Veriler EKG kaydı yapan sağlık çalışanlarının gözlemlendiği, her EKG kaydını acil tıp uzmanlarının değerlendirdiği ve EKG çekme yöntemine ilişkin anketin uygulandığı üç aşamada toplanmıştır. Çalışmanın tanımlayıcı istatistiklerinde frekans ve yüzde değerleri, değişkenler arasındaki ilişkinin belirlenmesinde Pearson Corelasyon analizi kullanılmıştır.

Bulgular: Sağlık çalışanlarının EKG kaydı yapmaya ilişkin bilgi düzeyleri ile işlemin doğru yapılması arasında istatistiksel açıdan anlamlı ilişki ( $p>0.05$ ) yoktur. EKG'yi yorumlayan acil tıp uzmanları EKG raporlarının yarıya yakınında yorumlamayı kısıtlayan bir durum olduğunu, \%46'sında bu durumun çekim hatasından kaynaklandığını bildirmişlerdir ve EKG çekiminin \%22'si tekrar edilmiştir. Göğüs elektrotları hem teorik hem de pratik uygulamada yüksek oranda (\%100-\%80) yanlış konumlandırılmıştır.

Sonuç: EKG kaydı yapan sağlık çalışanlarının işleme ilişkin bilgisi ile işlem sırasında bu bilgiye uygun davranış yapmaları arasında ilişki olmadığı ve AS'de çekilen EKG'lerin yarısına yakınında en az bir çekim hatası olduğu görüldü.

Anahtar kelimeler: Elektrokardiyografi, sağlık personeli, acil servis, tanı işlemi 


\section{Introduction}

EDs are the departments where diagnosis, treatment and care services are carried out for health problems that occur unexpectedly (1). According to the communiqué on the application procedures and principles of ED services in Turkey, it is a must to admit all patients who apply to ED and to perform the necessary emergency care practices (2). It is reported that annual application to ED of the Ministry of Health hospitals is approximately 88 million people in Turkey (1). EDs, where emergency interventions are performed for many different diseases, are complex environments where unpredictable crowdedness takes place. Electrocardiography (ECG) is one of the most effective and inexpensive ways of diagnosing cardiovascular diseases (CVD), which increasing rapidly around the world, (3) in ED. In addition to being applicable for all patient groups, the ECG procedure is also highly preferred since it is a non-invasive procedure (4).

It is important to perform ECG correctly in terms of detecting risky heart problems in the early period and making the right decision about the interventions to be performed for the patient (4). It has been reported that $17 \%$ to $24 \%$ of patients will have a different diagnosis after ECG recording performed with incorrect electrode positioning (5). Correct interpretation of an accurate ECG is indispensable for the diagnosis of life-threatening CVDs, rhythm disorders, and electrolyte changes (6).

In this context, correct ECG shooting will provide the most important contribution to the interpreter in terms of detecting life-threatening cardiac pathologies (5). In the study, it was aimed to identify the right and wrong applications of non-physician healthcare workers working in ED on the standard ECG method. It is considered that the results of the study will contribute to the prospective planning of emergency care practices and to increase the level of patient satisfaction by providing better quality emergency health services.

\section{Material and Methods}

36 non-physician healthcare workers who worked in the adult ED in Yozgat City Hospital and took ECGs and 14 healthcare workers who worked in the emergency department of Yozgat Bozok University Training, Research and Application Hospital and took ECGs constituted the sample of the study. All non-physician healthcare workers who took ECGs in the ED of both hospitals were included in the study, and the study was conducted with 50 (100\%) individuals. In addition, a total of six emergency medicine specialists working in the emergency departments of both hospitals contributed to the research. The study was conducted in three stages, which consisted of observing the ECG recording process, evaluating the ECG recording, and measuring the level of knowledge. The observations of 150 ECG recordings taken during the observation and interpreted by emergency medicine specialists were included in the study. In order not to cause bias in the research, the observer and the ECG interpreter are independent from each other.

\section{Data Collection Tools}

The observation form developed by the researcher in accordance with the literature $(5,7,8)$, the questionnaire form, and the evaluation form in which the opinions of emergency medicine specialists who evaluated the ECG report were determined were used as the data collection tools. One of the questions of the questionnaire was related to the placement of chest (precordial) electrodes in the correct anatomical region, and the participants were asked to either mark the image or match the correct anatomical regions of the V1-V6 electrodes. All participants (50) preferred to mark the visual. The - symbol was used for marking and it was indicated that the name of each sign (V1V6) should be written. Image (Figure 1) was a front view of the rib cage, sternum, and clavicles. The forms were reproduced from a single copy in order to mark on the picture with the same dimensions in all questionnaire forms. A survey scale picture drawn on copy paper consisting of squares with $1 \mathrm{~mm}$ horizontal and $1 \mathrm{~mm}$ vertical dimensions was used to create frequency maps that will accurately reflect the markings. Thus, the coordinates of the locations marked by the participants for each electrode were determined and transferred to the frequency maps for V1v6.

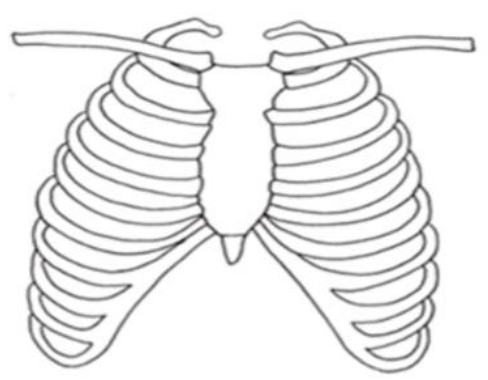

Figure 1. Chest anatomy

\section{Evaluation of Data}

The data obtained from the study were evaluated using the SPSS 20.0 package program in the computer environment. Frequency and percentage values were used in the descriptive statistics of the study. Whether there was a statistically significant relationship between the two variables of the study was identified by Pearson Correlation analysis.

\section{Ethical concerns}

The approval of Yozgat Bozok University Faculty of Medicine Clinical Research Independent Ethics Committee 2017-KAEK189_2019.02_20, and the written permissions from Yozgat 
Evaluation of ECG Recording Applications

Health Directorate and the administrative unit of the hospital, where the study would be conducted, were obtained before the study (92198657-771). Written and verbal informed consent was obtained from the participants prior to data collection for the study, which was conducted in accordance with all human research standards under the Declaration of Helsinki.

\section{Limitations of the Research}

The limitation of this study is that it was not determined whether the interpretations of the Emergency Medicine specialists who evaluated the ECG were compatible with each other.

\section{Results}

Socio-demographic and working characteristics of the participants

Table 1 presents the distribution of the socio-demographic and working characteristics of the 50 healthcare workers who participated in the study and took ECGs. It was determined that while $68 \%$ of the non-physician healthcare workers who participated in the study were female, $58 \%$ of them were married, $46 \%$ of them were between the ages of $22-27$, and $44 \%$ of them had working experience in the ED for more than 5 years. Furthermore, it was found that while $52 \%$ of them had bachelor's degree, $30 \%$ of them were high school graduates, and $18 \%$ of them had associate degree, $60 \%$ of them were nurses, $40 \%$ of them were emergency medical technicians, $84 \%$ of them worked in shifts, and $58 \%$ of them did not receive in-service training on ECG shooting (Table 1).

\begin{tabular}{|c|c|c|c|}
\hline $\begin{array}{l}\text { Introductory characteristics of } \\
\text { workers }\end{array}$ & on-physician healthcare & $\mathrm{n}$ & $\%$ \\
\hline \multirow{2}{*}{ Gender } & Male & 16 & 32 \\
\hline & Female & 34 & 68 \\
\hline \multirow[t]{3}{*}{ Marital status } & Married & 29 & $5^{8}$ \\
\hline & Single & 21 & 42 \\
\hline & 22-27 years & 23 & 46 \\
\hline \multirow{4}{*}{ Age } & 28-33 years & 9 & 18 \\
\hline & $34-39$ years & 16 & 32 \\
\hline & 40-43 years & 2 & 4 \\
\hline & 6 months-1 year & 16 & 32 \\
\hline \multirow{3}{*}{$\begin{array}{l}\text { Years of working in the } \\
\text { emergency department }\end{array}$} & 2-4 years & 12 & 24 \\
\hline & 5 years and more & 22 & 44 \\
\hline & High school & 15 & 30 \\
\hline \multirow[t]{3}{*}{ Educational level } & Associate degree & 9 & 18 \\
\hline & Undergraduate & 26 & 52 \\
\hline & Nurse & 30 & 60 \\
\hline \multirow{3}{*}{ Title } & Emergency & & \\
\hline & technician & 20 & 40 \\
\hline & Shift & 42 & 84 \\
\hline \multirow[t]{2}{*}{ Work shedule } & Only night & 6 & 12 \\
\hline & Only daytime & 2 & 4 \\
\hline Receiving in-service training on & Received & 21 & 42 \\
\hline ECG shooting & Did not receive & 29 & 58 \\
\hline
\end{tabular}

Table 1. Distribution of socio-demographic and working characteristics of healthcare workers shooting ECG
Comparison of the observations during the ECG procedure and the responses to the questionnaire

The distribution of the healthcare workers' responses to the questions regarding ECG shooting prepared in line with the guidelines of the Society for Cardiological Science and Technology (SCST), and the results obtained by observation is presented in Table 2. It was observed that the tendency to correct behavior was low (2\%) although more than half of the participants (74\%) knew that hands should always be washed before the procedure before ECG shooting (1-7 items), and wearing gloves before the procedure was preferred instead of hand washing. Contrary to eight people who thought that the chest hair should be shaved before the procedure if necessary in male patients, the procedure was not performed. Although more than half of the participants (58\%) knew that the metal objects on the patient should be removed in all cases, the procedure was never applied during the shooting. Among the participants, it was found that those who believed that the patient should be informed before the procedure (74\%) were more than those who informed the patient during the shooting (42\%). It was observed that $28 \%$ of the participants received patient consent before the procedure, which was compatible with those who thought that patient consent should be obtained before the procedure (28\%). It was determined that the most attentive behavior of all ECG practitioners in the preprocedure period was to protect the patient's privacy (90\%) (Table 2).

During the ECG shooting procedure (Items 8-14), it was observed that the tendency to exhibit correct behavior for positioning the hand-foot electrodes on the correct limb $(100 \%)$, placing hand-foot electrodes two to three fingers above the wrist (88\%), ensuring full contact of the electrodes with the attached area (84\%), and enabling patients to rest (52\%) was higher compared to other procedure steps. However, it was observed that ECG practitioners' tendency to exhibit correct behavior for positioning the hand-foot electrodes $(6.7 \%)$ of the patients with tremor higher was very low. None of the participants used gel to increase the conductivity of the electrodes, they generally used alcohol to increase the conductivity. Furthermore, it was observed that the behavioral tendency to position the chest (precordial) electrodes in the correct anatomical region $(20 \%)$ was quite weak. It was determined that the results of the correct anatomical region markings on the picture in the questionnaire (Figure 2) were similar to the observation results (Table 2 ).

After the end of the ECG procedure (15-20 items), although it was generally accepted (94\%) among the participants that the patient should be informed that the procedure was over, it was observed that the procedure was performed by $20 \%$. Although alcohol was applied to the patients instead of conductive gel, it was found that they were not helped at all 


\begin{tabular}{|c|c|c|c|c|c|c|c|}
\hline \multirow[b]{2}{*}{ Procedure Steps } & \multicolumn{3}{|c|}{ Questionnaire } & \multicolumn{2}{|c|}{ Observation } & \multicolumn{2}{|c|}{ Test } \\
\hline & I agree & $\begin{array}{c}\text { Should be performed } \\
\text { occasionally }\end{array}$ & I disagree & Performed & $\begin{array}{l}\text { Did not } \\
\text { perform }\end{array}$ & $\mathrm{r}$ & $\mathrm{p}$ \\
\hline Questions & $\mathrm{n}(\%)$ & $\mathrm{n}(\%)$ & $\mathrm{n}(\%)$ & $\mathrm{n}(\%)$ & $\mathrm{n}(\%)$ & & \\
\hline $\begin{array}{l}\text { 1. Every patient should be informed } \\
\text { about the procedure }\end{array}$ & $37(74)$ & $13(26)$ & $0(0,0)$ & $21(42)$ & $29(58)$ & 0,042 & 0,770 \\
\hline 2. Patient consent should be obtained & $14(28)$ & $21(42)$ & $15(30)$ & $14(28)$ & $36(72)$ & $-0,159$ & 0,270 \\
\hline 3. Patient privacy should be ensured & $50(100)$ & $0(0,0)$ & $0(0,0)$ & $45(90)$ & $5(10)$ & _ & _- \\
\hline $\begin{array}{l}\text { 4. Hands should be washed before the } \\
\text { procedure }\end{array}$ & $37(74)$ & $7(14)$ & $6(12)$ & $1(2)$ & $49(98)$ & $-0,128$ & 0,374 \\
\hline $\begin{array}{l}\text { 5. Room temperature should be } 22-24 \\
{ }^{\circ} \mathrm{C}\end{array}$ & $27(54)$ & $20(40)$ & $3(6)$ & $50(100)$ & $0(0,0)$ & 0,113 & 0,435 \\
\hline $\begin{array}{l}\text { 6. Men's chest hair should be shaved if } \\
\text { necessary }\end{array}$ & $8(16)$ & $26(52)$ & $16(32)$ & $0(0,0)$ & $61(100)$ & $-0,075$ & 0,605 \\
\hline $\begin{array}{l}\text { 7. It is ensured that the patient removes } \\
\text { metal items/the patient's metal items } \\
\text { are removed }\end{array}$ & $29(58)$ & $17(34)$ & $4(8)$ & $0(0,0)$ & $50(100)$ & - & - \\
\hline $\begin{array}{l}\text { 8. The patient should be rested before } \\
\text { the procedure }\end{array}$ & $36(72)$ & $14(28)$ & $0(0,0)$ & $26(52)$ & $24(48)$ & $-0,153$ & 0,288 \\
\hline $\begin{array}{l}\text { 9. Hand-foot electrodes should be } \\
\text { placed on the wrists with a distance of } 3 \\
\text { fingers. }\end{array}$ & $40(80)$ & $10(20)$ & $\mathrm{O}(0,0)$ & $44(88)$ & $6(12)$ & $-0,185$ & 0,199 \\
\hline $\begin{array}{l}\text { 10. Hand-foot electrodes should be } \\
\text { placed higher in people with tremor }\end{array}$ & $19(38)$ & $25(50)$ & $6(12)$ & $1(6,7)$ & $14(93,3)$ & $-0,024$ & 0,867 \\
\hline $\begin{array}{l}\text { 11. Electrodes should be placed after } \\
\text { applying gel. }\end{array}$ & $19(38)$ & $22(44)$ & $9(18)$ & $0(0,0)$ & $50(100)$ & - & - \\
\hline $\begin{array}{l}\text { 12. Correct electrode placement in the } \\
\text { hand-foot area }\end{array}$ & $50(100)$ & $0(0,0)$ & $0(0,0)$ & $50(100)$ & $0(0,0)$ & - & - \\
\hline $\begin{array}{l}\text { 13. The full contact of the electrodes } \\
\text { with the body should be ensured }\end{array}$ & $50(100)$ & $0(0,0)$ & $0(0,0)$ & $42(84)$ & $8(16)$ & - & - \\
\hline $\begin{array}{l}\text { 14. Electrodes should be attached to the } \\
\text { correct area in the chest area }\end{array}$ & $49(98)$ & $1(2)$ & $0(0,0)$ & $10(20)$ & $40(80)$ & 0,071 & 0,622 \\
\hline $\begin{array}{l}\text { 15. The patient's name and surname } \\
\text { should be written on the ECG report. }\end{array}$ & 49 (98) & $1(2)$ & $0(0,0)$ & $43(86)$ & 9 (18) & $-0,053$ & 0,716 \\
\hline $\begin{array}{l}\text { 16. Date and time information should } \\
\text { be written on the ECG report }\end{array}$ & $40(80)$ & $9(18)$ & $1(2)$ & $38(76)$ & $12(24)$ & $-0,065$ & 0,653 \\
\hline $\begin{array}{l}\text { 17. The patient should be informed that } \\
\text { the procedure is over. }\end{array}$ & 47 (94) & $3(6)$ & $0(0,0)$ & $10(20)$ & $40(80)$ & $-0,101$ & 0,486 \\
\hline $\begin{array}{l}\text { 18. It is necessary to help cleaning the } \\
\text { gel residues on the skin }\end{array}$ & $33(66)$ & $14(28)$ & $3(6)$ & $0(0,0)$ & $50(100)$ & - & - \\
\hline $\begin{array}{l}\text { 19. ECG machine, cables and electrodes } \\
\text { should be cleaned at the end of the } \\
\text { procedure }\end{array}$ & $38(76)$ & $11(22)$ & $1(2)$ & $1(2)$ & $49(98)$ & 0,077 & 0,595 \\
\hline
\end{tabular}

to dry their skin. It was observed that cleaning $(2 \%)$ of the ECG machine and its apparatus was almost never applied. According to the Pearson Correlation analysis, it was observed that there was no statistically significant relationship between healthcare workers' level of knowledge about accurate recording of ECG and their practical applications ( $p>0.05$ ) (Table 2).

Questionnaire and observation results on the correct positioning of the limb and chest electrodes

In the study, it was a remarkable result that the tendency to place the chest electrodes in the correct anatomical region was very low. Therefore, this subject was examined in detail within the scope of the study. The results on the questionnaire responses of healthcare workers performing ECG shooting on the correct positioning of the limb and chest electrodes, and the observations are presented in Table 3.
It was determined that both the questionnaire (100-96\%) and observation (100-98\%) results of the limb electrodes were similar and that the application was carried out correctly at a very high rate. However, the questionnaire results on the positioning of the chest (precordial) electrodes
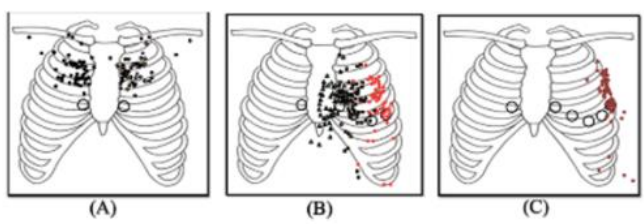

Figure 2. Markings made by non-physician healthcare workers performing ECG shooting for correct anatomical site placement in the questionnaire; (A) placement

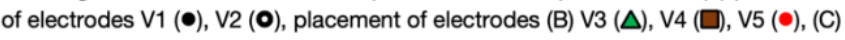
frequency maps of the placement of electrode V6 $(\bullet)$ 


\begin{tabular}{|c|c|c|c|c|c|c|}
\hline & Questionnaire res & & & & Observation & \\
\hline Limb Derivations & $\begin{array}{c}\text { Correct region } \\
\mathrm{n}(\%)\end{array}$ & $\begin{array}{c}\text { Wrong region } \\
\mathrm{n}(\%)\end{array}$ & $\begin{array}{l}\text { Total } \\
\mathrm{n}(\%)\end{array}$ & $\begin{array}{c}\text { Correct region } \\
\mathrm{n}(\%)\end{array}$ & $\begin{array}{c}\text { Wrong region } \\
\mathrm{n}(\%)\end{array}$ & $\begin{array}{l}\text { Total } \\
\text { n (100) }\end{array}$ \\
\hline Right arm & $50(100)$ & $0(0,0)$ & $50(100)$ & $150(100)$ & $0(0,0)$ & $150(100)$ \\
\hline Left arm & $50(100)$ & $0(0,0)$ & $50(100)$ & $150(100)$ & $0(0,0)$ & $150(100)$ \\
\hline Right leg & $48(96)$ & $2(4)$ & $50(100)$ & $149(98)$ & $1(2)$ & 150 (100) \\
\hline Left leg & $48(96)$ & $2(4)$ & $50(100)$ & $149(98)$ & $1(2)$ & $150(100)$ \\
\hline $\begin{array}{l}\text { Chest Derivations } \\
\qquad V_{1} \text { red }\end{array}$ & $0(0,0)$ & $50(100)$ & $50(100)$ & $83(55,3)$ & $67(44,7)$ & $150(100)$ \\
\hline$V_{2}$ yellow & $0(0,0)$ & $50(100)$ & $50(100)$ & $82(54,7)$ & $68(45,3)$ & $150(100)$ \\
\hline$V_{3}$ green & $0(0,0)$ & $50(100)$ & $50(100)$ & $54(36,0)$ & $96(64,0)$ & $150(100)$ \\
\hline $\mathrm{V}_{4}$ brown & $6(12)$ & $44(88)$ & $50(100)$ & $102(68,0)$ & $48(32,0)$ & $150(100)$ \\
\hline $\mathrm{V}_{5}$ black & $7(14)$ & $43(86)$ & $50(100)$ & $101(67,3)$ & $49(32,7)$ & $150(100)$ \\
\hline V6 purple & $9(18)$ & $41(82)$ & $50(100)$ & $104(69,3)$ & $46(30,7)$ & $150(100)$ \\
\hline
\end{tabular}

Table 3. Comparison of the questionnaire and observation results on the correct positioning of the limb and chest electrodes

in the correct anatomical regions and the observed behavior regarding the procedure were found to be applied incorrectly at very high rates. The frequency maps created as a result of the responses of all participants to the questionnaires regarding the placement of electrode are presented in Figure 2.

It was observed that the healthcare workers who performed ECG shooting positioned the chest electrodes V1, V2 and V3 on the $100 \%$ wrong anatomical region on the visual given in the questionnaire. Furthermore, it was also found that incorrect anatomical regions were marked for the position of the chest electrodes V4 (84\%), V5 (86\%) and V6 (82\%). It was determined that the tendency to position the chest electrodes (V1-V6) in the wrong anatomical regions during the observed ECG shootings was high (80\%) but more optimistic than the questionnaire results.

Results on the Evaluation of the ECG report by the Emergency Medicine specialist

Table 4 shows the distribution of the evaluations of the emergency medicine specialists, who evaluated the ECG report, regarding the effect of the shooting procedure on the interpretation. It was indicated that there were images that limited interpretation in nearly half of the ECG reports (48\%), which was due to the shooting error in $46 \%$ of them, and accordingly, the doctors decided to repeat $22 \%$ of the ECG shootings. Nevertheless, the observer found that $6.7 \%$ of the procedure was repeated during the ECG shooting.

\section{Discussion}

In this study, it was found that non-physician healthcare workers in the ED had correct information about 10 steps out of 20 procedures according to the guideline on ECG shooting approved by SCST, and the behavior during the procedure was compatible. However, it was determined that the correct behavior tendency was inconsistent despite having the correct information about the nine procedure steps. In their study, Fordyce et al. (2003) investigated errors in the intensive emergency department setting, and the result of the study was consistent with the fact that the errors related to diagnostic studies were among the most common and reported errors with by $22 \%$ (9), which was considered to be due to the fact that the ECG shooting procedure was learned through the master-apprentice relationship and that sufficient time cannot be allocated to the patient since the number of ED employees was not sufficient to meet the intense admissions (10).

\begin{tabular}{|c|c|c|c|}
\hline \multirow{3}{*}{ Clinical Doctor's Evaluation } & \multicolumn{3}{|c|}{ Clinical Doctor's Decision } \\
\hline & Yes & No & Total \\
\hline & $\mathrm{n}(\%)$ & $\mathrm{n}(\%)$ & $\mathrm{n}(\%)$ \\
\hline $\begin{array}{l}\text { Presence of a condition that limits } \\
\text { ECG interpretation }\end{array}$ & $72(48)$ & $78(52)$ & $150(100)$ \\
\hline $\begin{array}{l}\text { Presence of shooting error that } \\
\text { prevents ECG interpretation }\end{array}$ & $69(46)$ & $81(54)$ & $150(100)$ \\
\hline Repeating the ECG recording & $33(22)$ & $117(78)$ & $150(100)$ \\
\hline $\begin{array}{l}\text { Repeating the procedure during } \\
\text { ECG recording }\end{array}$ & $10(6,7)$ & $140(93,3)$ & $150(100)$ \\
\hline
\end{tabular}

The applications such as shaving the chest hair of male patients (61), removing metal objects on the patient before the procedure, and placing the electrodes after applying the gel, that were determined in accordance with SCST's recommendations (7) in order to obtain a clear image in the advisory ECG recordings, were never performed. It was observed that only one of the patients with tremor (15) had the hand-foot electrodes positioned higher. This result is consistent with the evaluations of emergency medicine specialists, who stated that there was a situation that 
prevented the interpretation of the ECG recording in more than half of the recordings (Table 4).

Hand washing and cleaning the ECG machine after each procedure, which are among the measures to prevent hospital infections, were almost never performed. In their study, Kesapli et al. (2004) evaluated handwashing habits in EDs and found that healthcare workers washed their hands by $20.8 \%$ after total contact (11). In their study, Barnsley et al. (2004) evaluated the clinical skills of young healthcare workers and reported that the most common types of errors were observed in sterile or aseptic technique areas (12). In all three studies, the use of sterile or aseptic techniques by healthcare workers was very low. It is observed that these results are inconsistent with the infection prevention recommendations recommended in the SCST guideline (7). The fact that gloves are worn before each procedure and that the procedure is not an invasive procedure creates false confidence in infection prevention among healthcare workers.

In this study, a limited number of procedures regarding patient rights, such as informing the patient before the procedure, informing the patient that the procedure is over, and obtaining patient consent (7), were performed, which indicated that healthcare workers working in ED had a negative behavior tendency in terms of providing quality service based on patient rights. Considering the results of the questionnaire, it is understood that healthcare workers had a high level of knowledge on these issues. The result led to the opinion that the level of knowledge determined by questionnaire studies was an insufficient indicator in terms of providing evidence that the application was performed correctly.

It was determined that the tendency to place the chest electrodes (V1-V6) in the wrong anatomical region during ECG shootings was high, but it was more optimistic than the questionnaire results. It was thought that this difference was due to the fact that the observer considered the obvious errors (electrodes positioned 5-10 cm away from the correct area) as incorrect application. It was ironic that more than half of the participants positioned the chest electrodes correctly during the procedure, but they chose the wrong position for almost all electrodes in the questionnaire. The fact that imaging is obtained on the ECG machine, regardless of the correct or incorrect position of the electrodes, leads to the perception that the procedure is performed correctly among healthcare workers, and they naturally assume that they have positioned the electrodes correctly.

Identifying the greatest field effect in the anterior part of the left ventricle of the heart is possible by positioning the V2 electrode in the 4th intercostal space, to the left of the sternum. In the literature, it is reported that the effect of the left ventricle will decrease in the image of the V1 electrode positioned higher $(5,13)$. The questionnaire results of this study showed that none of the participants positioned the V1, V2, and V3 electrodes in the correct region. However, it was observed that the 1st and 2 nd intercostal spaces were mostly preferred for the positioning of V1 and V2, and that the electrodes were positioned higher by $44.7 \%$ (V1) and $45.3 \%$ (V2) during the procedure. In their study, Bond et al. (2012) found that practitioners positioned the V2 electrode incorrectly by $17 \%$ to $24 \%$ (5). Medani et al. (2018) reported in their study that the most common mispositioning was too high placement of V1 and V2 electrodes (8). Furthermore, Khunti (2014) found that the tendency to place the V1-V2 electrodes incorrectly was high (14). The results of all three studies are similar to the results of this study.

In the present study, it was determined that wrong place was determined in the questionnaire for the V3 electrode location by $100 \%$ and that the participants made this mistake during the procedure by $82 \%$. With the questionnaire, it was also determined that the tendency to place the V4 (88\%), V5 (86\%) and V6 (82\%) electrodes incorrectly was high. Kanie et al. (2014) reported that $2 \mathrm{~cm}$ deviation from standard chest electrode placement led to significant changes in the QRS complex in descending order in the V2, V3, V1 and V4 derivations (15). Therefore, according to the results of this study, it is considered that incorrect positioning of V1, V2, V3 and $\mathrm{V} 4$ electrodes may lead to misdiagnosis.

In the study, it was found that the chest electrode configurations were highly misplaced in the EDs of both hospitals, which may result in two negative situations for the patients. The first one is the delay of the patient's diagnostic procedures and the possibility of administering some unnecessary treatments to the patient (16). The second one is the possibility of applying cardiac catheterization to the patient with a high risk of morbidity and mortality (16).

\section{Conclusion}

It was found that there was no relationship between the fact that the non-physician healthcare workers in the ED chose the right application in the questionnaire prepared in line with the SCST-approved ECG procedure guide, and the correct application in practice. It was observed that healthcare workers applied the configuration of the chest electrodes incorrectly, especially the V1-V2-V3 electrodes were placed in the wrong anatomical region. Such studies can guide the identification of other clinical applications and interventions that are performed/not performed correctly in practice.

Based on the results of the study, it is recommended to provide healthcare workers with periodic in-service training on ECG shooting, interpretation and correct positioning of chest electrodes, to use a separate and special area for ECG shooting in order to reduce the factors that limit the obtaining of clear images from the ECG of the female and 
Evaluation of ECG Recording Applications

male population, and to employ healthcare workers with cardiology clinical experience in these areas if possible for ECG shooting.

Conflict of Interest: The author declare no any conflict of interest regarding this study.

Financial Disclosure: The author declared that this study received no financial support.

Author Contribution: This article was written by a single author.

Ethical Approval: Ethical approval for this study was obtained from Yozgat Bozok University Hospital Ethics Committee with the approval number E-71522473050.01.04-32190-307.

Author declared that she follow the rules of Research and Publication Ethics.

Acknowledgments : I am grateful to the healthcare workers working in the ED of both hospitals, where the study was conducted, for their contributions to the study. This study would not be conducted without them. I would also like to thank the administrative staff of Yozgat City Hospital for the opportunities and support they provided me during the study.

\section{References}

1. Bayraktar AK, Sivrikaya SK. Nursing Ethics in the Emergency Department. Journal of Education and Research in Nursing, 2018;15(1): 57-63.

2. Turkish Statistical Institute (2018), Access address: www.tuik.gov.tr (25-8) date of access: 04.02.2019.

3. Global atlas on cardiovascular disease prevention and control. Geneva, World Health Organisation (2011), Access address: https://apps.who.int/iris/handle/10665/44701 date of access: 04.02.2019

4. Rudiger A, Hellermann JP, Mukherjee R, Follath F, Turina J. Electrocardiographic artifacts due to electrode misplacement and their frequency in different clinical settings. The American Journal of Emergency Medicine 2007; 25(2): 174-78. https://doi.org/10.1016/j.ajem.2006.06.018.

5. Bond RR, Finlay DD, Nugent CD, Breen C, Guldenring D, Daly MJ. The effects of electrode misplacement on clinicians' interpretation of the standard 12-lead electrocardiogram. European Journal of internal Medicine 2012; 23(7): 610-15. doi:10.1016/j.ejim.2012.03.011.

6. Lynch R. ECG lead misplacement: A brief review of limb lead misplacement. African Journal of Emergency Medicine 2014; 4(3):13039. http://dx.doi.org/10.1016/j.afjem.2014.05.006

7. Eldridge J, Richley D, Baxter S, Blackman S, Cathal JB, Brown C, et al. Recording a standard 12-lead electrocardiogram. An approved methodology by the Society of Cardiological Science and Technology (SCST). Clinical Guidelines by Consensus; 2014. . Web publication/site http://uir.ulster.ac.uk/30479/1/CAC_SCST_Recording_a_12lead_ECG_final_version_2014_CS2v2.0.pdf

8. Medani SA, Hensey M, Caples N, Owens P. Accuracy in precordial ECG lead placement: improving performance through a peer-led educational intervention. Journal of Electrocardiology 2018; 51(1): 504. doi: 10.1016/j.jelectrocard.2017.04.018.
Aydemir

9. Fordyce J, Blank FS, Pekow P, Smithline HA, Ritter G, Gehlbach S, et al. Errors in a busy emergency department. Annals of Emergency Medicine. 2003; 42(3), 324-333. https://doi.org/10.1016/S01960644(03)00398-6.

10. Di Somma S, Paladino L, Vaughan L, Lalle I, Magrini L, Magnanti M. Overcrowding in emergency department: an international issue. Internal and Emergency Medicine. 2015; 10(2), 171-175. DOI 10.1007/s11739-014-1154-8.

11. Keşaplı $M$, Çete $Y$, Kartal $M$. Characteristics and influencing factors of handwashing behavior in the emergency department. Turkey Clinics Journal of Medical Sciences 2004; 24(3): 235-42.

12. Barnsley L, Lyon PM, Ralston SJ, Hibbert EJ, Cunningham I, Gordon FC, et al. Clinical skills in junior medical officers: a comparison of selfreported confidence and observed competence. Medical Education. 2004; 38(4), 358-367. https://doi.org/10.1046/j.13652923.2004.01773.x

13. Garcia T. Acquiring the 12-lead electrocardiogram: doing it right every time. Journal of Emergency Nursing 2015; 41(6): 474-78. http://dx.doi.org/10.1016/j.jen.2015.04.014

14. Khunti K. Accurate interpretation of the 12-lead ECG electrode placement: A systematic review. Health Education Journal. 2014; 73(5), 610-623. https://doi.org/10.1177/0017896912472328

15. Kania M, Rix H, Fereniec M, Zavala-Fernandez H, Janusek D, Mroczka T, et al. The effect of precordial lead displacement on ECG morphology. Medical \& Biological Engineering \& Computing 2014; 52(2):109-19. DOI: 10.1007/s11517-013-1115-9.

16. Thaler T, Tempelmann V, Maggiorini M, Rudiger A. The frequency of electrocardiographic errors due to electrode cable switches: a before and after study. Journal of Electrocardiology. 2010; 43(6), 676-681. https://doi.org/10.1016/j.jelectrocard.2010.05.007 